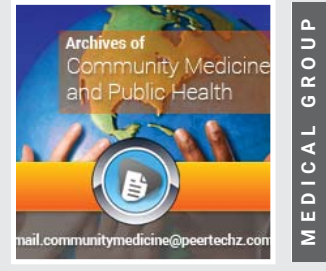

\section{Occupational burnout}

\section{Tzu-Ching Sung*}

School of Medicine for International Students, College of Medicine, I-Shou University, Kaohsiung, Taiwan
Received: 30 March, 2020

Accepted: 10 April, 2020

Published: 11 April, 2020

*Corresponding author: Tzu-Ching Sung, MS, PhD, School of Medicine for International Students, I-Shou University, No. 8, Yida Rd., Jiaosu Village, Yanchao District, Kaohsiung City 82445, Taiwan, Tel: 886-7615-1100 ext.7971; E-mail: d91841001@ntu.edu.tw; vivian1223@isu.edu.tw

https://www.peertechz.com
During the 1960s, the term "burnout" originated as an explanation of the effect on an individual who struggled with substance use disorder [1]. Burnout was first identified as a potential cause of attrition in various fields by Freudenberger in 1974 [2]. Since 1974, many scientific studies on this mental circumstance have been published. Freudenberger defined burnout as an individual who were exhausted by extreme demands on energy, capitals, or strength that would lead them to become ineffective in achieving the intents and purposes [3]. Numerous published studies on this mental condition cited Freudenberger as the first to describe burnout [4]. Burnout has been widely deliberated health problems of mental condition. People may face socioeconomic challenges, and confront the increasing pressure in their daily lives, predominantly in the workplace. Consequently, those in various professions and subdivisions suffer from work-related exhaustion, fatigue, and stress. The most noticeable marks are often denoted as burnout syndrome [4].

Burnout has been formally documented as a syndrome that could increase the potential medical use of people, and an occupational phenomenon in the International Classification of Diseases (ICD) of the World Health Organization (WHO) since May 2019. Burnout is classified as an occupational phenomenon in the ICD-11 resulting from chronic stress in the workplace that has not been controlled. Burnout is not a medical condition or illnesses, but the reasons for contact health services [5]. Three dimensions are described as follows: Feelings of exhaustion or vigor reduction; feelings of negativism or cynicism or an increase in mental distance from work; and decreased professional efficacy.

Burnout, as we know, is now an official workplace syndrome. There has been no generally accepted definition until the development of a widely accepted description. One of the most prominent characterizations is a psychological syndrome consistent with WHO's definition which comprises an emotional exhaustion (an overwhelming feeling or emotional response to incapability to cope with workplace demands), depersonalization (attitudes and behaviors marked by apathy, coldness, distance, indifference, cynicism and detachment from the job), and decreased personal accomplishment at work (a sense of ineffectiveness and poorer performance or feelings of not reaching achievement at work, and intense desires to change jobs) [6-8]. The most extensively used instrument to measure burnout syndrome is Maslach Burnout Inventory (MBI) that has been categorized into three types of Maslach Burnout Inventory-Educators Survey (MBI-ES), Maslach Burnout Inventory-Human Services Survey (MBI-HSS), and Maslach Burnout Inventory-General Survey (MBI-GS) [8].

A study indicated low levels of job satisfaction, support, coping strategies with stress, and high levels of emotional exhaustion were associated with high levels of burnout. Low stress tolerance and high levels of burnout seem to be associated with a suppressed hypothalamus-pituitary-adrenal axis and low levels of cortisol (i.e. the main stress hormone secreted by the adrenal glands). In particular, stress and burnout are proven to be separate variables are proven i.e. people may not feel stress but report burnout [9]. Burnout has been shown to be caused by extremely chronic stress and emotional stimulation in psychology and physiology. Work stress is continually accumulating and reaching towards chronically critical levels [10]. The development of work stress can be caused by adverse working conditions and management practices [11]. Furthermore higher levels of burnout symptoms and perceived stress at workplace are found to be correlated to maladaptive and passive coping strategies among people with type D personality $[12,13]$. Occupational burnout is considered a major problem that needs further and regular surveillance within the workplace.

\section{References}

1. Golembiewski RT (1993) Handbook of organizational behavior. New York, NY: Marcel Dekker. 
2. Freudenberger HJ (1974) Staff burn-out. Journal of Social 30: 159-165. Link: https://bit.ly/3eelBjt

3. Freudenberger HJ (1975) The staff burn-out syndrome in alternative institutions. Psychotherapy: Theory, Research and Practice. 12: 73-82. Link: https://bit.ly/3aX67yw

4. Heinemann LV, Heinemann T (2017) Burnout Research: Emergence and Scientific Investigation of a Contested Diagnosis. Sage Open 1-12. Link: https://bit.ly/2Xp7pyc

5. WHO (2019) Burn-out an "occupational phenomenon": International Classification of Diseases. Link: https://bit.ly/2RmL1I

6. Maslach C, Leiter MP (2016) Understanding the burnout experience: recent research and its implications for psychiatry. World Psychiatry 15: 103-111. Link: https://bit.ly/3c6PPmH

7. Maslach C, Jackson SE, Leiter MP (1996) MBI: The Maslach Burnout Inventory manual. $3^{\text {rd }}$ ed. Palo Alto, CA: Consulting Psychologists Press. Link: https://bit.ly/34rnFQI

8. Maslach C, Jackson SE, Leiter MP, Schaufeli WB, Schwab RL (1986)
Maslach burnout inventory. Palo Alto: Consulting Psychologists Press. Link: https://bit.ly/39ZfVH1

9. Pruessner JC, Hellhammer DH, Kirschbaum C (1999) Burnout, perceived stress, and cortisol responses to awakening. Psychosom Med 61: 197-204. Link: https://bit.ly/34r5evr

10. APA (2012) Stress in America: Our Health at Risk. Washington, DC, USA American Psychological Association.

11. Bhui K, Dinos S, Galant-Miecznikowska M, de Jongh B, Stansfeld S (2016) Perceptions of work stress causes and effective interventions in employees working in public, private and non-governmental organisations: a qualitative study. BJPsych Bull 40: 318-325. Link: https://bit.ly/2UXAr6n

12. Polman R, Borkoles E, Nicholls AR (2010) Type D personality, stress, and symptoms of burnout: the influence of avoidance coping and social support. Br J Health Psychol 15: 681-696. Link: https://bit.ly/2ylNtfk

13. Oginska-Bulik N (2006) Occupational stress and its consequences in healthcare professionals: the role of type D personality. Int J Occup Med Environ Health 19: 113-122. Link: https://bit.ly/3c8C473

\section{Discover a bigger Impact and Visibility of your article publication with} Peertechz Publications

\footnotetext{
Highlights

* Signatory publisher of ORCID

* Signatory Publisher of DORA (San Francisco Declaration on Research Assessment)

* Articles archived in worlds' renowned service providers such as Portico, CNKI, AGRIS, TDNet, Base (Bielefeld University Library), CrossRef, Scilit, J-Gate etc.

* Journals indexed in ICMJE, SHERPA/ROMEO, Google Scholar etc.

* OAI-PMH (Open Archives Initiative Protocol for Metadata Harvesting)

* Dedicated Editorial Board for every journa

* Accurate and rapid peer-review process

* Increased citations of published articles through promotions

* Reduced timeline for article publication

Submit your articles and experience a new surge in publication services (https://www.peertechz.com/submission).
}

Peertechz journals wishes everlasting success in your every endeavours.

Copyright: (c) 2020 Sung TC. This is an open-access article distributed under the terms of the Creative Commons Attribution License, which permits unrestricted use, distribution, and reproduction in any medium, provided the original author and source are credited. 